\title{
Studies on the Effects of Oxygen on Acetylene Reduction (Nitrogen Fixation) in Gloeothece sp. ATCC 27152
}

\author{
By JOHN R. GALLON* AND A. FALAH HAMADI \\ Department of Biochemistry, University College of Swansea, Singleton Park, \\ Swansea SA2 8PP, UK
}

(Received 13 July 1983)

Cultures of Gloeothece sp. ATCC 27152 did not reduce acetylene when exposed to $\mathrm{O}_{2}$ concentrations greater than $0.7 \mathrm{~atm}$. However, following exposure to $1 \mathrm{~atm} \mathrm{O}_{2}$ for up to $12 \mathrm{~h}$ or to $0.8 \mathrm{~atm} \mathrm{O}_{2}$ for up to $14 \mathrm{~d}$, the ability to reduce acetylene recovered rapidly when cultures were returned to air. Complete recovery required active protein synthesis, probably for de novo synthesis of nitrogenase. Respiratory $\mathrm{O}_{2}$ consumption by cultures of Gloeothece was stimulated under elevated concentrations of $\mathrm{O}_{2}$. This respiration may contribute to the protection of nitrogenase from inactivation by $\mathrm{O}_{2}$ at concentrations up to $0.4 \mathrm{~atm}$. The role of $\mathrm{Ca}^{2+}$ in nitrogen fixation may be related to respiratory protection.

\section{INTRODUCTION}

Among the various organisms that fix $\mathrm{N}_{2}$, the properties of nitrogenase (EC 1.18.2.1) are remarkably constant. For example, nitrogenase is extremely sensitive to inactivation by $\mathrm{O}_{2}$ and it is now well-documented that $\mathrm{N}_{2}$-fixing organisms have evolved a variety of mechanisms in order to protect this enzyme from damage by $\mathrm{O}_{2}$ (Gallon, 1981). Cyanobacteria are unique among $\mathrm{N}_{2}$-fixing organisms in that they evolve $\mathrm{O}_{2}$ as a result of their photosynthesis. Accordingly, $\mathrm{N}_{2}$-fixing cyanobacteria are able to protect nitrogenase from both photoevolved and atmospheric $\mathrm{O}_{2}$. Precisely how this protection is achieved is not understood, but it appears to involve a combination of different mechanisms (Gallon, 1981; Gotto et al., 1979).

Gloeothece (formerly Gloeocapsa) is a unicellular cyanobacterium capable of aerobic $\mathrm{N}_{2}$ fixation. It does not possess the differentiated heterocysts that characterize most aerotolerant $\mathrm{N}_{2}$-fixing cyanobacteria (Haselkorn, 1978). In Gloeothece, $\mathrm{N}_{2}$ fixation and photosynthetic $\mathrm{O}_{2}$ evolution coexist within a single, undifferentiated cell type. Although cultures of Gloeothece, grown under an alternating cycle of light and darkness, effect an almost complete temporal separation of photosynthesis and $\mathrm{N}_{2}$ fixation (Mullineaux et al., 1981), cultures grown under constant illumination evolve $\mathrm{O}_{2}$ and fix $\mathrm{N}_{2}$ simultaneously. Like heterocystous cyanobacteria, Gloeothece appears to use a variety of strategies in order to protect nitrogenase from $\mathrm{O}_{2}$ damage. Among these are a superoxide-metabolizing system (Tözüm \& Gallon, 1979) and an unidentified $\mathrm{Ca}^{2+}$-dependent mechanism (Hamadi \& Gallon, 1981). However, these may well be supplemented by other systems.

In this paper, we describe a more detailed study of additional mechanisms by which the nitrogenase of Gloeothece sp. ATCC 27152 might be protected from inactivation by $\mathrm{O}_{2}$. In addition, we attempt to identify the role of $\mathrm{Ca}^{2+}$ in $\mathrm{O}_{2}$ protection.

\section{METHODS}

Growth of cultures. Gloeothece sp. ATCC 27152 (American Type Culture Collection, Rockville, Md., USA) was grown aerobically in 15 litres of sterile medium, free of combined nitrogen (Tözüm \& Gallon, 1979). Plectonema boryanum UTEX594 (University of Texas Culture Collection, Austin, Texas, USA) was grown similarly, either

Abbreviation: Disulfiram, tetraethylthioperoxydicarbonic diamide. 
aerobically in medium containing $2 \mathrm{~mm}-\mathrm{NaNO}_{3}$, or in nitrogen-free medium sparged with $\mathrm{N}_{2}$ containing $0.03 \%$ (viv) $\mathrm{CO}_{2}$.

Acetylene reduction ( $N_{2}$ fixation). During incubation of cultures of Gloeothece under various gas phases, acetylene reduction was measured as described by Tözüm et al. (1977). The effect of transient exposure to $\mathrm{O}_{2}$ was measured as follows. Exponentially growing cultures of Gloeothece $\left(10^{5}-10^{6}\right.$ cells $\left.\mathrm{ml}^{-1}\right)$, harvested 6 to $9 \mathrm{~d}$ after inoculation, were concentrated five-fold by settling under gravity and $50 \mathrm{ml}$ samples were incubated aerobically, with stirring, at $25^{\circ} \mathrm{C}$, in sealed $150 \mathrm{ml}$ Erlenmeyer fiasks. Illumination at $2.5 \mathrm{klx}\left(17 \mu \mathrm{E} \mathrm{m}^{-2} \mathrm{~s}^{-1}\right)$ was provided by Osram white fluorescent lights. Acetylene was added to $0.01 \mathrm{~atm}$ and $0.5 \mathrm{ml}$ samples of the gas phase were removed after various incubation periods for determination of ethylene by gas chromatography. After 20 min incubation, the experimental culture was bubbled with either $\mathrm{O}_{2}$ or $\mathrm{O}_{2} / \mathrm{N}_{2}(1: 1, \mathrm{v} / \mathrm{v})$ for $2 \mathrm{~min}$, followed by $1 \mathrm{~min}$ with air. Control cultures were bubbled with air for $3 \mathrm{~min}$. The flasks were then resealed, acetylene added to $0.01 \mathrm{~atm}$ and further $0.5 \mathrm{ml}$ samples of the gas phase removed at suitable intervals during the following 2 to $3 \mathrm{~h}$.

Longer-term exposure to $\mathrm{O}_{2}$ was achieved by bubbling cultures of Gloeothece (2-15 litres) with $\mathrm{O}_{2}$ or with $\mathrm{O}_{2} / \mathrm{N}_{2}$ $(4: 1, \mathrm{v} v)$ containing $0.03 \%(\mathrm{v} / \mathrm{v}) \mathrm{CO}_{2}$. Samples $(50 \mathrm{ml})$ were then removed and incubated aerobically for a suitable period after which acetylene reduction was measured as described by Tözüm et al. (1977).

Respiratory $\mathrm{O}_{2}$ consumption. $\mathrm{O}_{2}$ consumption by $3 \mathrm{ml}$ samples of exponentially growing cultures of Gloeothece was measured polarographically at $25^{\circ} \mathrm{C}$ in the dark, in a Clark-type $\mathrm{O}_{2}$ electrode (Rank Bros., Bottisham, Cambs., UK). The cultures used were either unconcentrated or concentrated threefold by settling under gravity. The electrode was calibrated with air-saturated water and the concentration of dissolved $\mathrm{O}_{2}$ was altered by bubbling with $\mathrm{O}_{2}$ or $\mathrm{N}_{2}$ and also by illumination of cultures at $6 \mathrm{klx}\left(66 \mu \mathrm{E} \mathrm{m}^{-2} \mathrm{~s}^{-1}\right)$ under a tungsten lamp, before measurement of $\mathrm{O}_{2}$ consumption. Control incubations, with boiled cells, were included throughout and all data are corrected for $\mathrm{O}_{2}$ exchange in these controls.

$\mathrm{O}_{2}$ consumption by broken cell preparations of Gloeothece, prepared in 50-mM-HEPES/NaOH (pH 7.5) as described by Tözüm \& Gallon (1979), was also measured polarographically. The reaction mixture ( $3 \mathrm{ml}$ ) contained $32 \mathrm{~mm}-\mathrm{HEPES} / \mathrm{NaOH}(\mathrm{pH} 7.5), 1 \mathrm{~mm}-\mathrm{MgCl}_{2}$ and $0.5 \mathrm{ml}$ of a broken cell preparation of Gloeothece. NADH or NADPH ( $5 \mu \mathrm{mol})$ was added to start the reaction followed, in some cases, 2 to $5 \mathrm{~min}$ later by addition of ADP $(5 \mu \mathrm{mol})$ and $\mathrm{KH}_{2} \mathrm{PO}_{4}(5 \mu \mathrm{mol})$.

Intracellular $\mathrm{Ca}^{2+}$. To minimize contamination by $\mathrm{Ca}^{2+}$, all reagents were of the highest purity available (BDH) and were dissolved in fresh double-distilled water. All solutions were stored in polypropylene containers and polypropylene vessels were used for all experimental manipulations.

Exponentially growing cultures of Gloeothece $(100 \mathrm{ml})$ were harvested 6 to $8 \mathrm{~d}$ after inoculation and were incubated in $5 \mathrm{mM}$-HEPES/ $\mathrm{NaOH}$ (pH 7.5) for $30 \mathrm{~min}$ with or without $1 \mathrm{~mm}$-EDTA. The cells were collected by centrifugation at $10000 \mathrm{~g}$ for $10 \mathrm{~min}$. They were then suspended in double-distilled water, washed twice with $0.2 \mathrm{mM}-\mathrm{MgCl}_{2}$ to saturate the chelating capacity of any EDTA present in solution (Azzi \& Chance, 1969), and then twice with double-distilled water and finally resuspended in $2 \mathrm{ml}$ double-distilled water. Cells were broken in a French press at $138 \mathrm{MPa}$ and centrifuged at $3200 \mathrm{~g}_{\mathrm{g}}$ for $20 \mathrm{~min}$. $\mathrm{KCl}$ was added to the supernatant to a final concentration of $1.35 \mathrm{M}$ and, after standing for $15 \mathrm{~min}$, the precipitate was removed by centrifugation at $35000 \mathrm{~g}$ for $20 \mathrm{~min}$. The $\mathrm{Ca}^{2+}$ concentration of a sample $(0.1 \mathrm{ml})$ of the supernatant was measured using the bioluminescent method of Blinks et al. (1978). Each assay contained, in a final volume of $1 \mathrm{ml}, 5 \mathrm{mM}$ PIPES $/ \mathrm{NaOH}$ (ph 6.5) and $0.15 \mathrm{M}-\mathrm{KCl}$. The reaction was started by addition of $20 \mu \mathrm{g}$ aequorin (Sigma) dissolved in $2 \mathrm{~mm}-\mathrm{KCl}$ and passed through a column of Sephadex G-25 immediately before use. Total luminescence during a $10 \mathrm{~s}$ integration time was measured at $30^{\circ} \mathrm{C}$ using a Biolumat LB 9500 photon counter (Laboratory Impex, Twickenham, Middlesex, UK). Calibration curves were obtained by taking through the extraction procedure standards containing $0.1 \mathrm{pmol}$ to $1 \mu \mathrm{mol} \mathrm{CaCl}_{2}$, with and without $1 \mathrm{mM}$-EDTA.

Other measurements. $\mathrm{H}_{2}$ evolution was measured as described by Bothe et al. (1977) using exponentially growing cultures of Gloeothece, concentrated 20-fold by settling under gravity and incubated in sealed $25 \mathrm{ml}$ bottles for 6 to $18 \mathrm{~h}$.

Lipoxygenase (EC 1.13.11.12) was assayed polarographically as described by Wallace \& Wheeler (1979). The assay mixture ( $3 \mathrm{ml}$ ) contained $50 \mathrm{~mm}$-sodium phosphate buffer, $\mathrm{pH} 6.8$ and $12 \mathrm{~mm}$-sodium linoleate. The reaction was started by addition of $0.5 \mathrm{ml}$ of a broken cell preparation of Gloeothece.

The purity of cyanobacterial cultures was routinely monitored by streaking cultures onto nutrient agar or onto $1 \%(w)$ agar containing growth medium supplemented with 10 mM-glucose and $0.02 \%(w / v)$ Casamino acids (Rippka et al.. 1979).

Cell numbers were measured in a haemocytometer (Tözüm \& Gallon, 1979).

\section{RESULTS AND DISCUSSION}

\section{$\mathrm{O}_{2}$ and acetylene reduction}

Illuminated cultures of Gloeothece sp. ATCC 27152, growing exponentially under aerobic conditions, exhibited maximum rates of acetylene reduction $\left(\mathrm{N}_{2}\right.$ fixation) under $0 \cdot 1 \mathrm{~atm} \mathrm{O}_{2}$ 


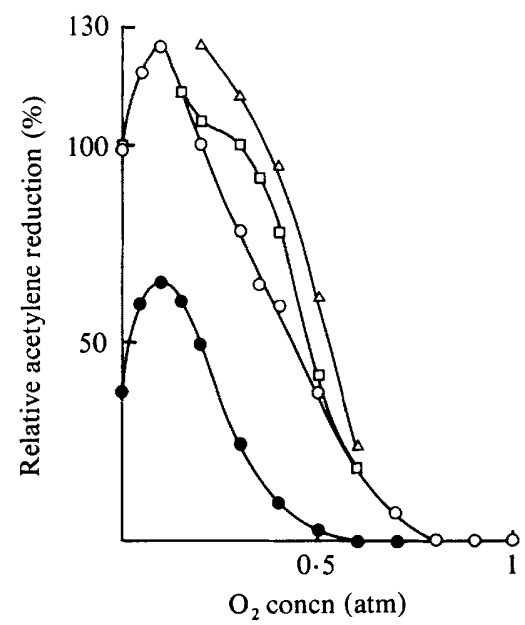

Fig. 1

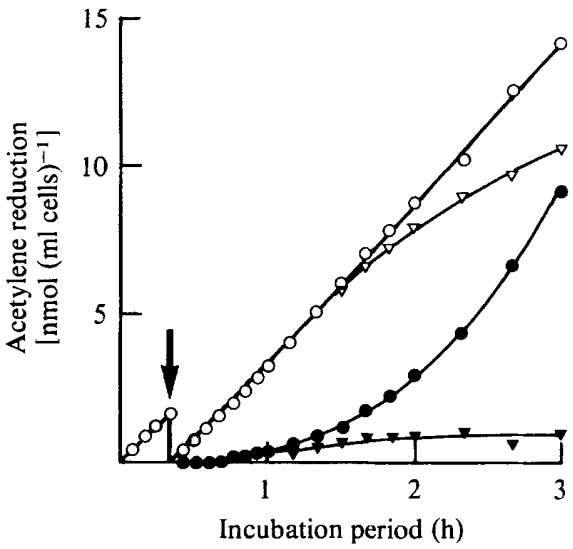

Fig. 2

Fig. 1. Effect of $\mathrm{O}_{2}$ on acetylene reduction by Gloeothece. Exponentially growing cultures $(50 \mathrm{ml})$ were incubated for $60 \mathrm{~min}$ under $\mathrm{N}_{2}$ containing $\mathrm{O}_{2}$ to the concentration indicated. Acetylene reduction was then measured during the following $60 \mathrm{~min}$. Incubation was either in the dark (O) or under illumination at $2.5 \mathrm{klx}$ with no additions $(O)$, with $5 \mathrm{~mm}-\mathrm{CaCl}_{2}(\square)$ or with $5 \mathrm{~mm}$-sodium ascorbate $(\triangle)$. Each value of the rate of acetylene reduction is the mean of at least eight separate observations and is expressed as a percentage of the rate in illuminated cultures with no additions, incubated under $0.2 \mathrm{~atm} \mathrm{O}_{2}$.

Fig. 2. Effect of transient exposure to $1 \mathrm{~atm} \mathrm{O}_{2}$ on acetylene reduction by Gloeothece. Cultures $(50 \mathrm{ml}$, concentrated fivefold) were incubated with 0.01 atm acetylene and samples removed for measurement of acetylene reduction as indicated. At the time marked by the arrow, cultures were bubbled for $3 \mathrm{~min}$ with air $(O, \nabla)$, or for $2 \mathrm{~min}$ with 1 atm $\mathrm{O}_{2}$ followed by $1 \mathrm{~min}$ with air $(\Theta, \nabla)$. At the same time, $0 \cdot 1 \mathrm{mg}$ chloramphenicol $\mathrm{ml}^{-1}$ was added to two of the cultures $(\nabla, \nabla)$. Because of variations in the absolute rate of acetylene reduction, the data shown are from a single experiment. However, the effects are typical of five independent experiments.

(Fig. 1). As the concentration of $\mathrm{O}_{2}$ was increased, the rate of acetylene reduction decreased, reaching zero above $0.7 \mathrm{~atm} \mathrm{O}_{2}$. Batch cultures of Gloeothece in the stationary phase of growth (10 to $14 \mathrm{~d}$ after inoculation) were rather more sensitive to elevated concentrations of $\mathrm{O}_{2}$. For example, whilst exponentially growing cultures consistently reduced acetylene $1 \mathrm{~h}$ after transfer to 0.6 atm $\mathrm{O}_{2}$ (Fig. 1), acetylene reduction by stationary phase cultures was completely inhibited under these conditions (data not shown).

The rate of acetylene reduction by illuminated cultures also decreased as the concentration of $\mathrm{O}_{2}$ in the gas phase fell below $0 \cdot 1 \mathrm{~atm}$ (Fig. 1). It appears, therefore, that photosynthesizing cultures of Gloeothece need atmospheric $\mathrm{O}_{2}$ in order to sustain maximum rates of acetylene reduction. Possibly, some respiratory activity is needed to supply reduced ferredoxin, ATP or carbon skeletons for $\mathrm{N}_{2}$ fixation. In this context, it may be significant that there is no unequivocal evidence that phostosynthesis directly provides reductant for $\mathrm{N}_{2}$ fixation in Gloeothece (Gallon, 1980).

Maximum rates of acetylene reduction also occurred under $0 \cdot 1$ atm $\mathrm{O}_{2}$ when exponentially growing cultures of Gloeothece were incubated in the dark. It appears, therefore, that atmospheric $\mathrm{O}_{2}$ is needed to sustain maximum rates of acetylene reduction in the dark, as in the light. However, because cultures of Gloeothece were able to fix $\mathrm{N}_{2}$ anaerobically in the dark (Fig. $1), \mathrm{O}_{2}$ is not an essential requirement for this process.

Acetylene reduction by cultures of Gloeothece incubated under 0.2 to $0.6 \mathrm{~atm} \mathrm{O}_{2}$ was stimulated by addition of $5 \mathrm{~mm}$-sodium ascorbate (Fig. 1). Sodium ascorbate also, to some extent, prevented methyl viologen from inhibiting acetylene reduction, and it may destroy toxic radicals produced by reduction of $\mathrm{O}_{2}$ (Tözüm \& Gallon, 1979). It is possible, therefore, that elevated concentrations of $\mathrm{O}_{2}$ may, in part, inhibit nitrogenase as a result of the production of toxic oxygen radicals. 


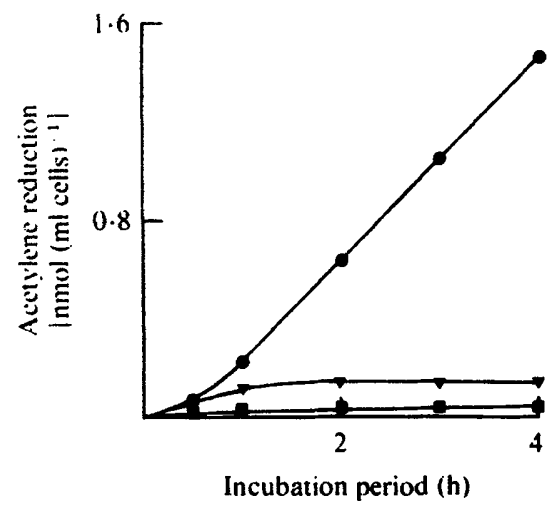

Fig. 3

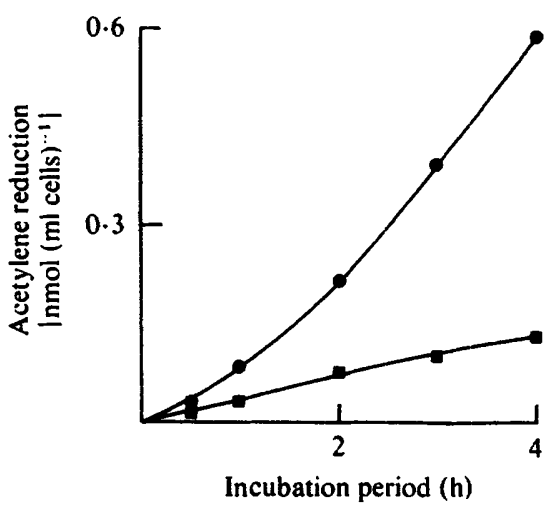

Fig. 4

Fig. 3. Effect of $12 \mathrm{~h}$ exposure to $1 \mathrm{~atm} \mathrm{O}_{2}$ on acetylene reduction by Gloeothece. Cultures ( 2 litres) were bubbled with $\mathrm{O}_{2}$ for $12 \mathrm{~h}$. Samples $(50 \mathrm{ml})$ were then removed and, after aerobic incubation for the period indicated. were assayed for acetylene reduction. To these cultures was added $5 \mathrm{mM}$ HEPES $\mathrm{NaOH}, \mathrm{pH} 7.5(\mathrm{O})$, along with $0.1 \mathrm{mg}$ chloramphenicol $\mathrm{ml}^{-1}(\nabla)$, or $2 \mathrm{mM}-\mathrm{NH}_{4} \mathrm{Cl}(\square)$. Although the data shown are from a single experiment they are typical of 12 experiments involving 1 to $12 \mathrm{~h}$ exposure to $\mathrm{O}_{2}$.

Fig. 4 Effect of $14 \mathrm{~d}$ exposure to $0.8 \mathrm{~atm} \mathrm{O}_{2}$ on acetylene reduction by Gloeothece. Cultures (15 litres) were bubbled with $\mathrm{O}_{2}: \mathrm{N}_{2}(4: 1, \mathrm{v} / \mathrm{v})$ containing $\left.0.03^{\circ}, \mathrm{v} / \mathrm{v}\right) \mathrm{CO}_{2}$ for $14 \mathrm{~d}$, after which $50 \mathrm{ml}$ samples were removed. To these was added $\mathrm{HEPES} / \mathrm{NaOH}(5 \mathrm{mM}), \mathrm{pH} 7.5(O)$, along with $2 \mathrm{mM}-\mathrm{NH}{ }_{4} \mathrm{Cl}(\square)$. Acetylene reduction was then measured after aerobic incubation for the period indicated. The data shown are from a single experiment but are typical of six experiments involving 1 to $14 \mathrm{~d}$ exposure to $0.8 \mathrm{dtm} \mathrm{O}$.

Illuminated cultures of Gloeothece, exposed to an inhibitory concentration ( 1 atm) of $\mathrm{O}_{2}$ for $2 \mathrm{~min}$. resumed acetylene reduction after a lag period of about $30 \mathrm{~min}$ following return to air. However, within $2 \mathrm{~h}$ the rate of acetylene reduction in treated cultures was comparable to that in control cultures which had not been exposed to $\mathrm{O}_{2}$ (Fig. 2). Exposure for $2 \mathrm{~min}$ to $0.5 \mathrm{~atm} \mathrm{O}_{2}$ had a similar effect although, in this case, acetylene reduction did not cease completely and recovered to its rate in control cultures within $1 \mathrm{~h}$ (results not shown). Recovery of acetylene reduction, following $2 \mathrm{~min}$ exposure to either 1 atm $\mathrm{O}_{2}$ (Fig. 2) or $0.5 \mathrm{~atm} \mathrm{O}_{2}$, was completely prevented by addition of $0.1 \mathrm{mg}$ chloramphenicol $\mathrm{ml}^{-1}$, implying that recovery was the result of de novo protein synthesis.

The length of the lag period that preceded reappearance of nitrogenase activity may be related to the length of exposure to $1 \mathrm{~atm} \mathrm{O}_{2}$. For example, whilst cultures of Gloeothece, exposed to

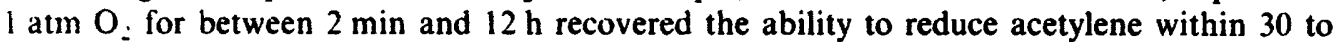
$60 \mathrm{~min}$ (Fig. 2, Fig. 3), cultures exposed to $1 \mathrm{~atm} \mathrm{O}_{2}$ for $24 \mathrm{~h}$ recommenced acetylene reduction only after a lag period of about $7 \mathrm{~h}$. Following $36 \mathrm{~h}$ exposure to $1 \mathrm{~atm} \mathrm{O}_{2}$, the lag period was $13 \mathrm{~h}$ and following $100 \mathrm{~h}$ exposure, a lag of $23 \mathrm{~h}$ preceded reappearance of acetylene reduction (data not shown). On the other hand, when cultures were exposed to $0.8 \mathrm{~atm} \mathrm{O}_{2}$ for between $24 \mathrm{~h}$ and $14 \mathrm{~d}$. the ability to reduce acetylene consistently returned within $1 \mathrm{~h}$ of transfer to air (Fig. 4). The pattern of recovery of nitrogenase activity following exposure of Gloeothece to elevated concentrations of $\mathrm{O}_{2}$ therefore appears to vary with respect to the concentration of $\mathrm{O}_{2}$ used, as well as with respect to the length of exposure to $\mathrm{O}_{2}$.

Nitrogenase synthesis appears to continue for up to $4 \mathrm{~h}$ in cultures of Gloeothece incubated under $1 \mathrm{~atm} \mathrm{O}_{2}$ (Mullineaux et al., 1983). This is in contrast to the repressive effect of $\mathrm{O}_{2}$ in some other $\mathrm{N}_{2}$-fixing organisms (Eady, 1981). The relatively short lag period before nitrogenase activity reappears following up to $12 \mathrm{~h}$ exposure to $1 \mathrm{~atm} \mathrm{O}_{2}$ or up to $14 \mathrm{~d}$ exposure to $0.8 \mathrm{~atm} \mathrm{O}_{2}$ suggests that synthesis of the enzyme might continue for periods longer than $4 \mathrm{~h}$ under elevated 
concentrations of $\mathrm{O}_{2}$. In contrast to the effect of $\mathrm{O}_{2}, 12 \mathrm{~h}$ exposure of immobilized cultures of Gloeothece to $0 \cdot 2 \mathrm{mM}-\mathrm{NH}_{4} \mathrm{Cl}$, which represses nitrogenase synthesis, resulted in no reappearance of nitrogenase activity for 7 to $12 \mathrm{~h}$ after removal of $\mathrm{NH}_{4} \mathrm{Cl}$ (Gallon et al., 1984). However, nitrogenase synthesis may not continue indefinitely under 1 atm $\mathrm{O}_{2}$ because a lag period of several hours preceded reappearance of nitrogenase activity following 24 to $100 \mathrm{~h}$ exposure to $\mathrm{O}_{2}$. Possibly, the carbon and/or nitrogen reserves of the cell became depleted during prolonged incubation under 1 atm $\mathrm{O}_{2}$, thereby inhibiting nitrogenase synthesis.

Although Gloeothece may continue to synthesize nitrogenase during exposure to elevated concentrations of $\mathrm{O}_{2}$, acetylene reduction was not observed at any time during $100 \mathrm{~h}$ exposure to $1 \mathrm{~atm} \mathrm{O}_{2}$ or during $14 \mathrm{~d}$ exposure to $\mathrm{O}_{2} / \mathrm{N}_{2}(4: 1, \mathrm{v} / \mathrm{v})$ containing $0.03 \%(\mathrm{v} / \mathrm{v}) \mathrm{CO}_{2}$. In the absence of $\mathrm{N}_{2}$-fixation, these cultures would become nitrogen-deficient during exposure to either $1 \mathrm{~atm}$ or $0.8 \mathrm{~atm} \mathrm{O}_{2}$. In view of this, it is more likely that depletion of cellular carbon, rather than cellular nitrogen, interrupted nitrogenase synthesis during 24 to $100 \mathrm{~h}$ exposure to $1 \mathrm{~atm} \mathrm{O}_{2}$.

Pienkos et al. (1983) have reported that cultures of Anabaena sp. CA, a heterocystous cyanobacterium, recover the ability to reduce acetylene within 30 to $60 \mathrm{~min}$ whilst still exposed to $1 \mathrm{~atm} \mathrm{O}_{2}$. In this organism, as in Gloeothece, nitrogenase synthesis apparently continues under elevated concentrations of $\mathrm{O}_{2}$, although the two organisms differ in their ability to maintain an active nitrogenase under these conditions. However, in both Gloeothece (Fig. 2, Fig. 3) and Anabaena CA (Pienkos et al., 1983) brief exposure to $\mathrm{O}_{2}$, followed by return to air, results in only a short lag period before acetylene reduction reappears. In contrast, in Anabaena flos-aquae, recovery of nitrogenase activity was not complete until 8 to $10 \mathrm{~h}$ after exposure for $10 \mathrm{~min}$ to 1 atm $\mathrm{O}_{2}$ (Bone, 1971). In some species of cyanobacteria, therefore, transient exposure to $\mathrm{O}_{2}$ may repress nitrogenase synthesis.

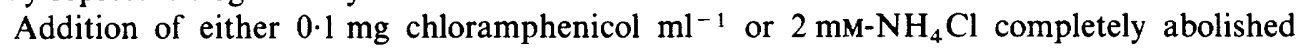
recovery of nitrogenase activity following transfer to air of cultures of Gloeothece, previously exposed to $1 \mathrm{~atm} \mathrm{O}_{2}$ for $12 \mathrm{~h}$ (Fig. 3). The involvement of protein synthesis in this recovery may therefore be for de novo synthesis of nitrogenase itself. However, although addition of $\mathrm{NH}_{4} \mathrm{Cl}$ to cultures exposed to $0.8 \mathrm{~atm} \mathrm{O}_{2}$ for $14 \mathrm{~d}$ markedly decreased the recovery of acetylene reduction, it did not prevent it completely (Fig. 4). In this latter case, as in Anabaena CA (Pienkos et al., 1983), it is possible that only part of the nitrogenase activity that reappears is the result of de noro synthesis of the enzyme. Some of the inactivation of nitrogenase by $0.8 \mathrm{~atm} \mathrm{O}_{2}$ may therefore be freely reversible.

The $\mathrm{N}_{2}$-fixing aerobe Azotobacter exhibits a reversible conformational protection of nitrogenase during transient exposure to elevated concentrations of $\mathrm{O}_{2}$ (Robson \& Postgate, 1980). A similar mechanism may exist in Gloeothece but there is little evidence for this (Hamadi \& Gallon, 1981). On the other hand, in cultures of Gloeothece exposed to $1 \mathrm{~atm} \mathrm{O}_{2}$ for $12 \mathrm{~h}$, and in cultures in which $\mathrm{O}_{2}$ inactivation of nitrogenase had been caused by addition of 1 mM-EDTA (Hamadi \& Gallon, 1981; Gallon, 1980), reappearance of nitrogenase activity may be entirely a consequence of synthesis of new enzyme. In these cases, inactivation of nitrogenase by $\mathrm{O}_{2}$ may have been irreversible.

It appears, therefore, that in Gloeothece synthesis of nitrogenase continues for several hours under 1 atm $\mathrm{O}_{2}$ and for several days under $0.8 \mathrm{~atm} \mathrm{O}_{2}$. Nevertheless, the enzyme is rapidly and, largely, irreversibly inactivated by exposure to $\mathrm{O}_{2}$ at these concentrations. Although continued synthesis of nitrogenase during $\mathrm{O}_{2}$ stress appears wasteful it may be advantageous in allowing rapid recovery of nitrogenase activity following return to less extreme conditions.

Plectonema boryanum is a non-heterocystous, filamentous cyanobacterium capable of $\mathrm{N}_{2}$ fixation under microaerobic, but not aerobic, conditions. However, Wang et al. (1982) have reported that, when incubated with extracts of Gloeothece, cultures of $P$. boryanum can fix $\mathrm{N}_{2}$ aerobically. Extracts of Gloeothece contain ascorbate and other reducing agents (Tözüm \& Gallon, 1979) and, in view of its stimulation of acetylene reduction in Gloeothece (Fig. 1), it is possible that ascorbate is responsible for the effect on $P$. boryanum of extracts of Gloeothece. In support of this, addition of $5 \mathrm{~mm}$-sodium ascorbate to cultures of $P$. boryanum UTEX 594 resulted in low, but consistent, rates of acetylene reduction during aerobic incubation. However, 


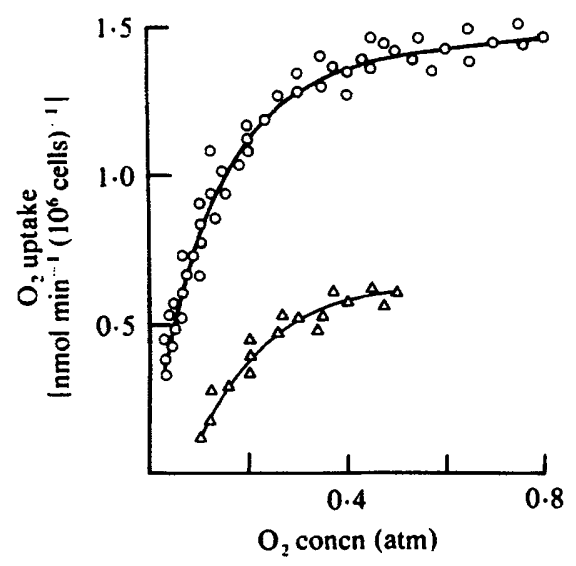

Fig. 5. Effect of $\mathrm{O}_{2}$ concentration on $\mathrm{O}_{2}$ uptake by cultures of Gloeothece. Both the rate of $\mathrm{O}_{2}$ uptake and the prevailing concentration of $\mathrm{O}_{2}$ were measured polarographically in $3 \mathrm{ml}$ samples of Gloeothece either with no additions $(O)$ or in the presence of $1 \mathrm{mM}-\mathrm{KCN}(\Delta)$. Each point represents an individual measurement, but the lines are drawn with reference to additional points which, for reasons of clarity, are not shown here. A concentration of $\mathrm{O}_{2}$ in the gas phase of $0.8 \mathrm{~atm}$ was equivalent to a dissolved $\mathrm{O}_{2}$ concentration of $1.03 \mu \mathrm{mol} \mathrm{ml}^{-1}$.

addition of sodium ascorbate did not allow aerobic growth of $P$. boryanum in nitrogen-free medium.

\section{Respiration in Gloeothece}

The rate of $\mathrm{O}_{2}$ consumption by cultures of Gloeothece, incubated in the dark, increased as the dissolved $\mathrm{O}_{2}$ concentration increased (Fig. 5). In this respect, Gloeothece resembles Azotobacter, where respiratory $\mathrm{O}_{2}$ consumption increased by a factor of five when the concentration of $\mathrm{O}_{2}$ was increased from 0.05 to $0.55 \mathrm{~atm}$ (Dalton, 1980). In Gloeothece the equivalent increase was 2.7-fold (Fig. 5). In Azotobacter respiration may function as an $\mathrm{O}_{2}$-scavenging mechanism which thereby protects nitrogenase from $\mathrm{O}_{2}$ (Yates \& Eady, 1980). Natural populations of Gloeothece probably fix most of their $N_{2}$ in the dark (Mullineaux et al., 1981), and under these conditions respiration may have a major role in protecting nitrogenase from inactivation by $\mathrm{O}_{2}$.

The greatest stimulation of respiratory $\mathrm{O}_{2}$ consumption in response to increasing concentrations of $\mathrm{O}_{2}$ took place between 0 and $0.4 \mathrm{~atm} \mathrm{O}_{2}$ (Fig. 5). Between 0.4 and $0.8 \mathrm{~atm} \mathrm{O}_{2}$, little further stimulation occurred and it is unlikely that respiratory $\mathrm{O}_{2}$ consumption would be very effective in protecting Gloeothece nitrogenase above $0.4 \mathrm{~atm} \mathrm{O}_{2}$. Consistent with this, exposure of Gloeothece to more than $0.7 \mathrm{~atm} \mathrm{O}_{2}$ led rapidly to complete cessation of acetylene reduction (Figs 1-4). The stimulatory effect of $\mathrm{O}_{2}$ on respiratory $\mathrm{O}_{2}$ consumption (Fig. 5) was measured within $15 \mathrm{~min}$ following exposure of cultures to the new concentration of $\mathrm{O}_{2}$. It is not known for how long these rates of respiration would be maintained, but it is unlikely to be for more than $1 \mathrm{~h}$. In support of this, preliminary data suggest that cultures of Gloeothece incubated in the dark for $1 \mathrm{~h}$ under 1 atm $\mathrm{O}_{2}$ exhibit rates of $\mathrm{CO}_{2}$ evolution and $\mathrm{O}_{2}$ consumption markedly lower than those in control cultures. It cannot therefore be assumed that respiratory $\mathrm{O}_{2}$ consumption could protect nitrogenase during prolonged exposure of cultures of Gloeothece to $\mathrm{O}_{2}$.

In Azotobacter, the respiratory chain is branched (Haddock \& Jones, 1977). The different branches have different sensitivities to various inhibitors, including $\mathrm{CN}^{-}$(Jones \& Redfearn, 1967). As a result of this branched electron transport chain, at high concentrations of $\mathrm{O}_{2}$ respiration in Azotobacter is poorly coupled to ATP synthesis and apparently functions primarily to consume $\mathrm{O}_{2}$.

Addition of $0.1 \mathrm{mM}$ - or $1 \mathrm{mM}-\mathrm{KCN}$ (Fig. 5) to cultures of Gloeothece partially inhibited respiratory $\mathrm{O}_{2}$ consumption. However, there was always residual $\mathrm{O}_{2}$ uptake of about $35 \%$ of the 
Table 1. Effect of various additions on $\mathrm{O}_{2}$ uptake by cultures of Gloeothece

\begin{abstract}
$\mathrm{O}_{2}$ uptake was measured polarographically in air using cultures $(3 \mathrm{ml})$ concentrated threefold under gravity. All incubations also contained $5 \mathrm{mM}-\mathrm{HEPES} / \mathrm{NaOH}, \mathrm{pH} 7 \cdot 5$. The rates of oxygen consumption are typical.
\end{abstract}

\section{Addition}

None

$0.1 \mathrm{mM}-\mathrm{KCN}$

$1 \mathrm{mM}-\mathrm{KCN}$

$1 \mathrm{mM}$-Salicylhydroxamate

$15 \mu \mathrm{M}$-Disulfiram

1 mM-EDTA

$5 \mathrm{~mm}-\mathrm{CaCl}_{2}$

$5 \mathrm{mM}^{-\mathrm{MgCl}_{2}}$

$1 \mathrm{mM}$-EDTA $+5 \mathrm{~mm}-\mathrm{CaCl}_{2}$

$1 \mathrm{mM}-\mathrm{EDTA}+5 \mathrm{~mm}-\mathrm{MgCl}_{2}$

$1 \mathrm{~mm}-\mathrm{EDTA}+1 \mathrm{~mm}-\mathrm{KCN}$

$\mathrm{O}_{2}$ consumption
$\left[\mathrm{nmol} \mathrm{min}^{-1}\left(10^{6} \text { cells }\right)^{-1}\right]$
1.00
0.37
0.32
1.00
1.00
0.60
1.04
0.81
0.91
0.63
0.12

uninhibited rate (Table 1). In higher plants, $\mathrm{CN}^{-}$-insensitive respiration has been equated with a branched electron transport chain (Lance, 1981), although recently this has been questioned on the grounds that lipoxygenase (EC 1.13.11.12) activity could explain $\mathrm{CN}^{-}$-resistant $\mathrm{O}_{2}$ uptake (Kelly, 1982). However, unlike $\mathrm{CN}^{-}$-resistant respiration in the mitochondria of higher plants, $\mathrm{O}_{2}$ uptake in Gloeothece was not inhibited by either salicylhydroxamate, an inhibitor of lipoxygenase (Parish \& Leopold, 1978), or disulfiram (Table 1). Furthermore, no lipoxygenase activity has been detected in extracts of Gloeothece.

The rate of $\mathrm{CN}^{-}$-resistant respiration in cultures of Gloeothece increased with increasing $\mathrm{O}_{2}$ concentration (Fig. 5). Between $0.1 \mathrm{~atm}$ and $0.2 \mathrm{~atm} \mathrm{O}_{2}$, the increase in the rate of $\mathrm{CN}^{-}$resistant respiration could entirely account for the increase in respiration observed in the absence of $\mathrm{CN}^{-}$. However, above $0 \cdot 2 \mathrm{~atm} \mathrm{O}_{2}$, although $\mathrm{CN}^{-}$-resistant respiration continued to increase, the increase was insufficient to explain the increase in $\mathrm{O}_{2}$ consumption by uninhibited cultures of Gloeothece. Presumably, $\mathrm{CN}^{-}$-sensitive respiration was also stimulated over this range of $\mathrm{O}_{2}$ concentrations.

It is therefore possible that Gloeothece, like Azotobacter, possesses a branched electron transport chain and that electron flow down a $\mathrm{CN}^{-}$-resistant branch is mainly, though not exclusively, stimulated under elevated concentrations of $\mathrm{O}_{2}$. By analogy with Azotobacter, this $\mathrm{CN}^{-}$-resistant branch may be poorly coupled to ATP synthesis and may function mainly to consume $\mathrm{O}_{2}$. Cultures of Gloeothece may, therefore, exhibit respiratory protection of nitrogenase.

In some species of cyanobacteria, $\mathrm{H}_{2}$ donates electrons via an 'uptake' hydrogenase to an electron transport chain with $\mathrm{O}_{2}$ as terminal acceptor (Bothe et al., 1980). The resulting $\mathrm{O}_{2}$ consumption may contribute to the protection of nitrogenase from damage by $\mathrm{O}_{2}$, particularly under conditions of carbon deficiency. Cultures of Gloeothece evolved little, if any, $\mathrm{H}_{2}$ either in the light or, aerobically or anaerobically, in the dark. However, in the presence of $12.4 \mathrm{mM}-\mathrm{C}_{2} \mathrm{H}_{2}$ and $0.124 \mathrm{~mm}-\mathrm{CO}$ (Bothe et al., 1977), $\mathrm{H}_{2}$ evolution could be measured at a rate of $24.6 \mathrm{pmol} \mathrm{h}^{-1}$ $\left(10^{6} \text { cells }\right)^{-1}$ in the light and of $4.8 \mathrm{pmol} \mathrm{h}^{-1}\left(10^{6} \text { cells }\right)^{-1}$ in the dark. This suggests that Gloeothece possesses an 'uptake' hydrogenase and may, therefore, recycle $\mathrm{H}_{2}$ evolved by the action of nitrogenase, possibly in an $\mathrm{O}_{2}$-consuming system. However, there is no direct evidence that $\mathrm{H}_{2}$ has a role in protecting Gloeothece nitrogenase from inactivation by $\mathrm{O}_{2}$ (Tözüm \& Gallon, 1979).

\title{
$\mathrm{Ca}^{2+}$ and acetylene reduction
}

Addition of EDTA to cultures of Gloeothece inhibits acetylene reduction by disruption of a $\mathrm{Ca}^{2+}$-dependent process by which nitrogenase is protected from $\mathrm{O}_{2}$ (Hamadi \& Gallon, 1981). EDTA acts by depleting the cyanobacterial cells of $\mathrm{Ca}^{2+}$. The intracellular concentration of 
$\mathrm{Ca}^{2}$ - in cultures of Gloeothece was $62 \mathrm{pmol}\left(10^{6} \text { cells }\right)^{-1}$ under normal growth conditions (equivalent, approximately, to $0.6 \mathrm{mM})$, but fell to $12 \mathrm{pmol}\left(10^{6} \text { cells }\right)^{-1}$ following addition of 1 mM-EDTA.

Addition of $5 \mathrm{mM}-\mathrm{CaCl}_{2}$ to $\mathrm{N}_{2}$-fixing cultures decreased the inhibitory effect on acetylene reduction of 0.2 to 0.5 atm $\mathrm{O}_{2}$, but was without effect at $\mathrm{O}_{2}$ concentrations outside these limits (Fig. 1).

EDTA (1 mM) inhibited respiratory $\mathrm{O}_{2}$ uptake (Table 1). This inhibition was prevented by simultaneous addition of $5 \mathrm{mM}-\mathrm{CaCl}_{2}$ but not of $5 \mathrm{mM}-\mathrm{MgCl}_{2}$. In this respect, the effect of EDTA on respiration resembles its effect on acetylene reduction (Gallon, 1978). However, EDTA did not permanently affect the intracellular concentration of ATP (Hamadi \& Gallon, 1981). It is possible, therefore, that EDTA inhibits a relatively uncoupled respiratory $\mathrm{O}_{2}$ uptake. In support of this, the effects of EDTA and $\mathrm{CN}^{-}$appear to be additive (Table 1).

In broken cell preparations of Gloeothece, addition of $5 \mathrm{mM}-\mathrm{CaCl}_{2}$ stimulated by $50 \%$ both $\mathrm{NADH}$ - and NADPH-dependent $\mathrm{O}_{2}$ uptake. Unstimulated rates were 10.9 and $14.8 \mathrm{nmol}-$ $\min ^{-1}$ (mg protein) $)^{-1}$ respectively. Stimulation was observed whether or not ADP and inorganic phosphate were also present. Furthermore, although oligomycin, an inhibitor of oxidative phosphorylation, at a concentration of $10 \mu \mathrm{g} \mathrm{ml}^{-1}$, decreased the rate of NADH- and NADPH-dependent $\mathrm{O}_{2}$ consumption to about $45 \%$ of their uninhibited rate, this residual $\mathrm{O}_{2}$ uptake was still stimulated by addition of $5 \mathrm{mM}-\mathrm{CaCl}_{2}$. The effect of $\mathrm{CaCl}_{2}$ on respiratory $\mathrm{O}_{2}$ consumption does not, therefore, depend upon simultaneous ATP synthesis and may be the result of stimulation of uncoupled electron flow.

$\mathrm{CaCl}_{2}(5 \mathrm{mM})$ did not greatly affect the recovery of nitrogenase activity following treatment of cultures of Gloeothece with 0.8 atm $\mathrm{O}_{2}$ for 2 to $7 \mathrm{~d}$. It is unlikely, therefore, that $\mathrm{Ca}^{2+}$ ions are specifically involved in this recovery.

In conclusion, therefore, the role of $\mathrm{Ca}^{2+}$ in $\mathrm{N}_{2}$ fixation by Gloeothece may be linked to respiratory protection of nitrogenase from $\mathrm{O}_{2}$. The mechanism by which $\mathrm{Ca}^{2+}$ ions affect respiration is not clear but may be related to membrane integrity. In support of this, $\mathrm{Ca}^{2+}$ prevented surface-active compounds from inhibiting acetylene reduction by Gloeothece (Hamadi \& Gallon, 1981).

The authors thank the Royal Society for the award of a Scientific Investigations Grant. They also thank Mrs J. H. Thomas for skilled technical assistance and Dr A. E. Chaplin for valuable discussions. In addition, the contributions to this work of Mr S. M. Batchelor and Miss T. J. Fairless are gratefully acknowledged.

\section{REFERENCES}

AzZl. A. \& Chance, B. (1969). The 'energized state' of mitochondria: lifetime and ATP equivalence. Biochimica et biophysica acta 189, 141-151.

Blinks. J. R., Mattingly. P. H., Jewell, B. R., VAN leelwen, M., Harrer, G. C. \& Allen, D. G. (1978). Practical aspects of the use of aequorin as a calcium indicator: assay, preparation, microinjection and interpretation of signals. Methods in Enzymology 57, 292-328.

BONE, D. H. (1971). Kinetics of synthesis of nitrogenase in batch and continuous culture of Anabaena flosaquae. Archiv für Mikrobiologie 80, 242-251.

Bothe. H., Tennigkeit, J., Eisbrenner, G. \& Yates, M. G. (1977). The hydrogenase-nitrogenase relationship in the blue-green alga Anabaena cylindrica. Planta 133, 237-242.

Bothe, H., Neuer, G., Kalbe, I. \& Eisbrenner, G. (1980). Electron donors and hydrogenase in nitrogen-fixing microorganisms. In Nitrogen Fixation, pp. 83-112. Edited by W. D. P. Stewart \& J. R. Gallon. London: Academic Press.

DAlTON, H. (1980). Chemoautotrophic nitrogen fix- ation. In Nitrogen Fixation, pp. 177-195. Edited by W. D. P. Stewart \& J. R. Gallon. London: Academic Press.

EADY, R. (1981). Regulation of nitrogenase activity. In Current Perspectives in Nitrogen Fixation, pp. 172181. Edited by A. H. Gibson \& W. E. Newton. Canberra: Australian Academy of Science.

GalloN, J. R. (1978). Calcium and nitrogen fixation in Gloeocapsa. Ecological Bulletins 26, 60-68.

GalloN, J. R. (1980). Nitrogen fixation by photoautotrophs. In Nitrogen Fixation, pp. 197-238. Edited by W. D. P. Stewart \& J. R. Gallon. London: Academic Press.

GalloN, J. R. (1981). The oxygen sensitivity of nitrogenase: a problem for biochemists and microorganisms. Trends in Biological Sciences 6, 19-23.

Gallon, J. R., Yunes, J. S. \& Chaplin, A. E. (1984). Studies on the mechanism whereby the pattern of illumination affects $\mathbf{N}_{2}$ fixation by Gloeothece. In Advances in Nitrogen Fixation Research, p. 224. Edited by C. Veeger \& W. E. Newton. The Hague: Nijhoff/Junk. 
Gotto, J. W., TABita, F. R. \& Van BaAlen, C. (1979). Mutants of Anabaena strain CA, altered in their ability to grow under nitrogen fixing conditions. Journal of Bacteriology 140, 327-332.

HADDOCK, B. A. \& JONES, C. W. (1977). Bacterial respiration. Bacteriological Reviews 41, 47-99.

Hamadi, A. F. \& Gallon, J. R. (1981). Calcium ions, oxygen and acetylene reduction (nitrogen fixation) in the unicellular cyanobacterium Gloeothece sp. 1430/3. Journal of General Microbiology 125, 391398.

Haselkorn, R. (1978). Heterocysts. Annual Review of Plant Physiology 29, 319-344.

Jones, C. W. \& Redfearn, E. R. (1967). The cytochrome system of Azotobacter vinelandii. Biochimica et biophysica acta 143, 340-353.

Kelly, G. J. (1982). How widespread are cyanide resistant mitochondria in plants? Trends in Biochemical Sciences 7, 233.

LANCE, C. (1981). Cyanide-insensitive respiration in fruits and vegetables. In Recent Advances in the Biochemistry of Fruit and Vegetables, pp. 63-84. Edited by J. Friend \& M. J. C. Rhodes. London: Academic Press.

Mullineaux, P. M., Gallon, J. R. \& Chaplin, A. E. (1981). Acetylene reduction (nitrogen fixation) by cyanobacteria grown under alternating light-dark cycles. FEMS Microbiology Letters 10, 245-247.

Mullineaux, P. M., Chaplin, A. E. \& Gallon, J. R. (1983). Synthesis of nitrogenase in the cyanobacterium Gloeothece (Gloeocapsa) sp. CCAP 1430/3. Journal of General Microbiology 129, 1689-1696.

PARISH, D. J. \& LEOPOLD, A. C. (1978). Confounding of alternate respiration by lipoxygenase activity. Plant Physiology 62, 470-472.
Pienkos, P. T., Bodmer, S. \& Tabita, F. R. (1983). Oxygen inactivation and recovery of nitrogenase activity in cyanobacteria. Journal of Bacteriology 153, 182-190.

RiPPKa, R., Deruelles, J., Waterbury, J. B., Herdman, M. \& Stanier, R. Y. (1979). Generic assignments, strain histories and properties of pure cultures of cyanobacteria. Journal of General Microbiology 111, 1-61.

Robson, R. L. \& Postgate, J. R. (1980). Oxygen and hydrogen in biological nitrogen fixation. Annual Review of Microbiology 34, 183-207.

TözüM, S. R. D., Ul-Haque, M. I., Chaplin, A. E. \& GALLON, J. R. (1977). The effect of fluoroacetate on acetylene reduction by Gloeocapsa. Biochemical Society Transactions 5, 1482-1484.

Tozum, S. R. D. \& Gallon, J. R. (1979). The effects of methyl viologen on Gloeocapsa sp. LB 795 and their relationship to the inhibition of acetylene reduction (nitrogen fixation) by oxygen. Journal of General Microbiology 111, 313-326.

Wallace, J. M. \& Wheeler, E. L. (1979). Two lipoxygenase isoenzymes and an activator in wheat germ. Phytochemistry 18, 389-393.

WANG, Y., HE, J. \& LI, S. H. (1982). Oxygenscavenging system protecting nitrogenase from oxygen in cells of blue-green algae. Zhiwu Xuebao 24, 231-240.

Yates, M. G. \& Eady, R. (1980). Physiology and regulation of nitrogen fixation. In Recent Advances in Biological Nitrogen Fixation, pp. 88-120. Edited by N. S. Subba Rao. London: Arnold. 